\title{
Analysis of Greek Middle-school Science Textbooks about Forces and Motion from the Perspective of Three-dimensional Learning
}

\author{
Margarita Papakonstantinou ${ }^{1}$, Michael Skoumios ${ }^{1 *}$ \\ ${ }^{1}$ Department of Primary Education, School of Humanities, University of the Aegean, GREECE
}

Received 25 March $2021 \cdot$ Accepted 11 August 2021

\begin{abstract}
According to the Next Generation Science Standards, science instructional materials can be efficient as long as they integrate three dimensions: science and engineering practices, crosscutting concepts and disciplinary core ideas. However, research investigating the integration of these three dimensions in the content of school science textbooks is particularly limited. The present study aims to propose a framework of analysis and investigate the integration of these three dimensions, in the content of Greek middle-school science textbooks about forces and motion. A total of 61 reports and activities included in these textbooks were analyzed. A framework of analysis called Three-Dimensional Learning Analysis Inventory (3DLAl), which assesses the integration of the three dimensions in the content of school textbooks, was developed. Data analysis showed that only some science and engineering practices, crosscutting concepts and disciplinary core ideas are integrated to a limited extent in the reports and activities of Greek middle-school science textbooks, while their coexistence in them is limited as well.
\end{abstract}

Keywords: crosscutting concepts, disciplinary core ideas, forces, middle school, school textbooks, science and engineering practices, three-dimensional learning

\section{INTRODUCTION}

Significant research has been conducted in the last twenty years on the way students learn and on the way science could be taught more effectively (Krajcik et al., 2014; NRC, 2012). However, research data demonstrates that many students neither understand science ideas and concepts (Shwartz et al., 2008) nor do they find science lessons interesting (Inkinen et al., 2020). Moreover, according to Programme for International Student Assessment (PISA) results, Greece is among the group of countries presenting lower performance than Organization for Economic Cooperation and Development (OECD) average in all PISA cycles from 2000 onwards. Therefore, science education for students in Greece is not considered satisfactory.

In order to improve students' science learning outcomes, the Next Generation Science Standards (NGSS) and the US National Research Council proposed a new Framework for K-12 Science Education based on three dimensions of science learning: science and engineering practices (SEPs), crosscutting concepts
(CCCs) and disciplinary core ideas (DCIs) (NGSS Lead States, 2013; NRC, 2012). Students should engage in SEPs so as to develop and use core ideas and crosscutting concepts in order to explain phenomena and solve problems (Krajcik et al., 2014). It has been emphasized that the three dimensions are not taught separately but should coexist among the teaching goals and the activities used for teaching and assessing students (NRC, 2012).

School textbooks play an important role in the learning process (Abd-El-Khalick et al., 2008; Sothayapetch et al., 2013). School textbooks dominate in the teaching process, as they are very often used by the teachers (OECD, 2007). More specifically, the school textbook is frequently the only means of teaching at school (Davis, 2009; Fan \& Zhu, 2007; Newton \& Newton, 2006; Weiss et al., 1989). It affects students' learning both directly, while the students interact with it (Braswell et al., 2001; Chiappetta \& Fillman, 2007), and indirectly due to the effect it has on the teachers and their instructional decisions during the teaching process (Moulton, 1997; Reys et al., 2003; Swanepoel, 2010).

(c) 2021 by the authors; licensee Modestum. This article is an open access article distributed under the terms and conditions of the Creative Commons Attribution License (http://creativecommons.org/licenses/by/4.0/). 


\section{Contribution to the literature}

- There is a need to establish frameworks on investigating the integration of science and engineering practices, crosscutting concepts and disciplinary core ideas (three dimensions of science learning) in the content of school science textbooks. In this study, a such framework, the Three-Dimensional Learning Analysis Inventory (3DLAI), was developed.

- This study investigated, through the 3DLAI framework, the integration and coexistence of three dimensions of science learning in the content of Greek middle-school science textbooks about forces and motion.

Therefore, the learning process is to a large extent shaped by school textbooks used by both teachers and students. That is the reason why the analysis of school textbooks has been the subject of systematic research.

Students making sense of phenomena or designing solutions to problems requires student performances that integrate elements of the SEPs, CCCs, and DCIs in instructional materials (NRC, 2012). Although students' engagement in SEPs, CCCs and DCIs is considered especially important for science education, research investigating the level of the integration of these three dimensions in the content of science school textbooks is particularly limited (Laverty et al., 2016). In this direction, developing frameworks through which school textbooks can be analyzed with regard to the three dimensions of science learning engaged is considered necessary. Therefore, it becomes evident that there is necessity of conducting research focused on proposing analysis frameworks through which the integration of SEPs, DCIs and CCCs as well as their coexistence in the content of science school textbooks can be investigated.

The present study proposes a framework that can be used to analyze textbooks for alignment to the three dimensions of science learning (SEPs, CCCs and DCIs) and, through this framework, investigates their integration in the content of school science textbooks (student's book and lab workbook) about forces and motion taught to 13-year-old middle-school students in Greece. It examines whether opportunities are provided to the students through the content of these school science textbooks to engage them with activities that integrate all three dimensions of science learning, in order they can deeply understand this content.

In particular, the present study intends to answer the following research questions:

(a) Which SEPs, CCCs and DCIs, and how often, integrate in the content of Greek middle-school science textbooks about forces and motion?

(b) To what extent all three dimensions of science learning (SEPs, CCCs, DCIs) coexist in the content of Greek middle-school science textbooks about forces and motion?

The unit of forces and motion was chosen from these textbooks for many reasons. This unit occupies most of their content. It is considered a very important unit of Physics. In school science, conceptual understanding of force and its effects on motion are a precondition to students' gaining further understanding on other science units (Carson \& Rowlands, 2005). Phenomena involving force and motion are familiar in everyday life and continually affect students. Students' conceptual difficulties have been well established and a substantial body of research has been formed, regarding students' alternative conceptions about force and motion (Halim et al., 2014; Jimoyiannis \& Komis, 2003). These alternative conceptions that students develop are highly resistant to change (Driver, 1989).

\section{THREE-DIMENSIONAL LEARNING}

Establishing learning environments where the students are initiated into the kinds of thinking, discussion and action used by scientists while developing and revising knowledge has been pursued in recent years (Bybee, 2014). In such learning environments, priority is not given to knowledge memorization, but to the active engagement of the students, who ask questions, investigate, explain the natural world (Schwarz et al., 2017), construct, use and critique knowledge (Miller et al., 2018).

According to the NGSS and the new Framework for K-12 Science Education introduced by the US National Research Council, science learning between preschool age and the last grade of upper high school should be based on three dimensions of science learning ("threedimensional learning") (NGSS Lead States, 2013; NRC, 2012): SEPs, CCCs and DCIs.

The first dimension of this framework (SEPs) describes the most important practices employed by scientists while investigating and creating models and theories about the world, and the practices engineers use in order to design and construct systems (NRC, 2012). According to NRC (2012), the eight science and engineering practices are as follows: (a) asking questions (for science) and defining problems (for engineering), (b) developing and using models, (c) planning and carrying out investigations, (d) analyzing and interpreting data, (e) using mathematics and computational thinking, (f) constructing explanations (for science) and designing solutions (for engineering), (g) engaging in argument from evidence and (h) obtaining, evaluating, and communicating information. 
The second dimension is the CCCs applied in all domains of science so as to bridge their boundaries (NRC, 2012). They form the basis for the explanations of the phenomena and are particularly important in science education because "these concepts help provide students with an organizational framework for connecting knowledge from the various disciplines into a coherent and scientifically based view of the world" (NRC, 2012, p. 83). Students manage to understand CCCs following their involvement in activities integrating DCIs and SEPs (Duschl, 2012; NRC, 1996, 2012). According to NRC (2012), the seven CCCs are as follows: (a) patterns, (b) cause and effect: mechanism and explanation, (c) scale, proportion, and quantity, (d) systems and system models, (e) energy and matter: flow, cycle, conservation, (f) structure and function and (g) stability and change.

The third dimension of this framework is DCIs. Science knowledge constantly advances and new facts arise. It is impossible to teach the students all science knowledge in detail within their school years. The mission of education is not to teach all the knowledge to the students but make them familiar with basic knowledge and practices so that they can later gain additional knowledge on their own (NGSS Lead States, 2013). Therefore, education should be limited to certain science core ideas. Specific criteria have been established, so that the core ideas can be determined, and have been grouped in four domains: physical sciences, life sciences, earth and space sciences, and engineering, technology and applications of science (NRC, 2012).

The goal of NGSS is essentially the same as the goal of STEM, but on a much larger scale. NGSS incorporates STEM though its SEPs and goes a step further to include the content known as DCIs as well as CCCs, which both help to put a structure to the content and skills being delivered (NGSS Lead States, 2013). In addition to fostering skills around STEM and overall engineering competency, the NGSS also focuses on enhancing scientific literacy amongst all students (Osborne, 2014).

\section{LITERATURE REVIEW}

Research focusing on analyzing school science textbooks is particularly extensive (e.g., Devetak \& Vongrinc, 2013; Liu \& Khine, 2016; Vojír \& Rusek, 2019). More specifically, it has mainly focused on the structural elements of textbooks (number of pages and chapters, proportion between textual and visual material), the textual material (types and conceptual concept) and the visual material (kinds of pictures, macroscopic and microscopic visual representations) (Devetak \& Vongrinc, 2013). A recent literature review by Vojír and Rusek (2019) studied research papers focusing on analyzing school science textbooks between 2000 and 2018. A total of 183 research papers were found focused on analyzing school science textbooks. A percentage of
$41 \%$ of research papers carried out analyses of school textbooks generally on science, while only $8 \%$ of them dealt with Physics textbooks. Many of the papers were on analysing textbooks from Europe (41\%) and from North America (28\%). The majority of these analyses focused on choosing and organizing the content, the instructional methodology, the illustrations as well as the language used in the school textbooks that were studied. Furthermore, over the years, there has been a continuous increase in the number of relevant research papers, which proves that the analysis of school textbooks is the subject of great research interest. In particular, it was found that over time there has been an increasing trend in the percentage representing the number of studies focused on analyzing school textbooks to the total number of published studies focused on science education.

Regarding Greek school science textbooks, they are analyzed with respect to their serving four aspects of scientific literacy. The analysis of the textbooks reached the conclusion that the textbooks mainly focus on the knowledge of science content aspect, whereas the other aspects of scientific literacy (e.g., the investigative nature of science, and the knowledge about science) are practically missing in all textbooks investigated (Kollas et al., 2007). Hatzinikita et al. (2008) compared the nature of the textual construction of the PISA science test items and the Greek school science textbooks. The results showed that while the linguistic mode of the PISA items tends to resemble texts falling within the public domain and the corresponding visual mode tends to resemble texts of the esoteric domain, school science textbooks tend to employ the linguistic and the visual mode in exactly the opposite way.

Among the studies focused on analyzing school science textbooks there are studies referring to the inquiry processes engaging in the content of textbooks. In particular, there have been studies aiming to distinguish the openness levels of the inquiries incorporating in the content of school science textbooks (Bell et al., 2005; Bulunuz et al, 2012; Fay et al., 2007; Germann et al., 1996; Herron, 1971; Lederman, 2009; Ma et al., 2019; Schwab, 1962; Wenning, 2007), while other studies focused on the presence of characteristics of the inquiry processes that integrate in the content of school science textbooks (Dunne et al., 2013; Kahveci, 2009; Aldahmash et al., 2016). These studies showed that textbooks are usually dominated by activities guided by the teacher (thus leaving hardly any initiatives to the students) and do not include sufficient characteristics of the inquiry processes. Yang and Liu (2016), and Yang, Yang, and Liu (2019) analyzed activities of school science textbooks and found that only some of their activities provided the students with sufficient opportunities to understand scientific concepts and inquiry processes. Cellitti et al. (2018), based on a framework they developed, analyzed science lessons that can be found 
on the Internet with regard to the dimensions of SEPs engaging in their content and found that only some of the practices engage in their activities and, more specifically, only some of their dimensions.

However, the frameworks used in the above studies for analyzing textbooks are focused on inquiry processes and do not separately investigate the SEPs, the DCIs and the CCCs integrating in the content of textbooks. Research conducted on analyzing school science textbooks with regard to the three learning dimensions is particularly limited. In particular, Tekkumru-Kisa et al. (2015) developed a framework (Task Analysis Guide in Science) for analyzing activities in relation to two axes, i.e., the integration of knowledge and practices as well as the cognitive demand of the activities. Though, even in this framework of analysis, the DCIs and the CCCs integrating in the content of school textbooks are not separately analyzed. Also, the EQuIP rubric examines whether the lessons are in line with the core positions of NGSS (Achieve, 2016). One axis of the above research refers to the three dimensions of science learning. However, no specific criteria for analyzing the lessons in relation to each dimension are included. Laverty et al. (2016) proposed the Three-Dimensional Learning Assessment Protocol (3D-LAP), which can be used for analyzing assessment activities as to whether they engage science practices, DCIs and CCCs and was used for analyzing Biology, Chemistry and Physics activities. It should be noted that engineering practices are not included in this framework.

Although the integration of the three dimensions of science learning in the content of instructional material intended for science education has been recognized as significant (Krajcik, 2015; NRC, 2012), it has been found that research focusing on analyzing instructional material used in teaching, in relation to the integration of these three dimensions in its content, is limited and is focused on only some of these three dimensions. Furthermore, there is particularly limited research focusing on the integration of these three dimensions in the instructional material, and especially in their coexistence in the activities of the instructional material, as well as research focusing on developing frameworks of analysis that assess the presence of the three dimensions (SEPs, CCCs and DCIs) in the instructional material. Also, the necessity of developing such frameworks of analysis has been pointed out (Lee et al., 2014; NRC, 2014; Pruitt, 2014). Therefore, there is an emerging need for conducting research focused on developing frameworks of analysis that assess the integration of the three dimensions of science learning in the content of school science textbooks so that, through these frameworks, school textbooks and any other additional instructional material used in science teaching can be analyzed.

\section{METHODOLOGY}

\section{Research Design}

Content analysis was used for investigating the research questions posed (Fauskanger \& Mosvold, 2014; Krippendorf, 2013). It is a widely spread and tested method for analyzing school textbooks (Strijbos et al., 2006), in line with the purpose of the present study, as it allows identification of the various SEPs, CCCs and DCIs included in the separate sections of the content of the school textbooks that were selected to be analyzed.

The research process was conducted in three stages. At first, units of analysis included in middle-school science textbooks about forces and motion were identified. Then the framework for analyzing the instructional material was developed and, through this framework, the instructional material was analyzed, data processing was conducted, and conclusions were drawn.

\section{Sample and Units of Analysis}

In Greece, at the beginning of each academic year, the students of each grade are provided by the Greek Ministry of Education and Religious Affairs with the school textbooks they are to be taught. There are specific textbooks for the students of each grade and all students receive the same textbooks.

The present study is focused on analyzing the chapters about forces and motion included in school textbooks used for teaching science to 13-year-old middle-school students in Greece. For their science lessons, students of second grade of middle school (13 years old) are provided with a student's book and a lab workbook.

Any conceptual thematic unit independent of the rest text and making complete sense was described as unit of analysis. This means that it has a beginning and an end, while its content is relatively independent, i.e., it can be identified and separated from the other units of analysis. In particular, every report (a type of text that describes how things are, presents information, classifies various entities and explains processes in natural phenomena), problem, question of the student's book and every experimental account (a type of text that contains steps, which show how a specific experimental task should be carried out) of the lab workbook was considered as a unit of analysis. The unit of analysis consists of the text part and the accompanying representations.

The research sample included all the units of analysis of the chapter about forces and motion of the second grade Greek middle-school Physics textbooks (student's book, lab workbook). There was a total of 61 units of analysis. 
Table 1 . The part of 3DLAI referring to science and engineering practices

\begin{tabular}{|c|c|c|}
\hline $\begin{array}{l}\text { Science and Engineering } \\
\text { Practices }\end{array}$ & Description & Yes No \\
\hline $\begin{array}{l}\text { Asking questions and } \\
\text { defining problems }\end{array}$ & $\begin{array}{l}\text { The instructional material provides the students with opportunities to ask questions or } \\
\text { define problems. }\end{array}$ & \\
\hline $\begin{array}{l}\text { Developing and } \\
\text { using models }\end{array}$ & $\begin{array}{l}\text { The instructional material provides the students with opportunities to create or use } \\
\text { models. }\end{array}$ & \\
\hline $\begin{array}{l}\text { Planning and carrying out } \\
\text { investigations }\end{array}$ & $\begin{array}{l}\text { The instructional material provides the students with opportunities to design or conduct } \\
\text { investigations }\end{array}$ & \\
\hline $\begin{array}{l}\text { Analyzing and interpreting } \\
\text { data }\end{array}$ & $\begin{array}{l}\text { The instructional material provides the students with opportunities to work with data, } \\
\text { which could include organizing or grouping the data in a table or a graph. These } \\
\text { opportunities may support the students in drawing conclusions from the data. }\end{array}$ & \\
\hline $\begin{array}{l}\text { Using mathematics and } \\
\text { computational thinking }\end{array}$ & $\begin{array}{l}\text { The instructional material provides the students with opportunities to use mathematical } \\
\text { skills (e.g., measurements) or concepts (e.g., sum) }\end{array}$ & \\
\hline $\begin{array}{l}\text { Constructing explanations } \\
\text { and designing solutions }\end{array}$ & $\begin{array}{l}\text { The instructional material provides the students with opportunities to construct scientific } \\
\text { explanations (relating to how or why a phenomenon takes place) or design solutions to } \\
\text { problems }\end{array}$ & \\
\hline $\begin{array}{l}\text { Engaging in argument from } \\
\text { evidence }\end{array}$ & $\begin{array}{l}\text { The instructional material provides the students with opportunities to construct, use or } \\
\text { present arguments based on evidence and reasonings in order to support of refute an } \\
\text { explanation a phenomenon or a solution for a problem. }\end{array}$ & \\
\hline Obtaining, evaluating and & $\begin{array}{l}\text { The instructional material provides the students with opportunities to obtain scientific } \\
\text { information from texts. }\end{array}$ & \\
\hline
\end{tabular}

Table 2. The part of 3DLAI referring to crosscutting concepts

\begin{tabular}{|c|c|c|}
\hline Crosscutting Concepts & Description & Yes No \\
\hline Patterns & $\begin{array}{l}\text { The instructional material provides the students with opportunities to identify patterns or } \\
\text { trends emerging from three or more events, observations, or data. }\end{array}$ & \\
\hline Cause and Effect: & The instructional material provides at most two of the following: a cause, an effect, and the & \\
\hline \multicolumn{3}{|c|}{$\begin{array}{l}\text { Mechanism and Explanation mechanism that links the cause and effect, as well as opportunities to the students to } \\
\text { provide the other(s) with. }\end{array}$} \\
\hline Scale, Proportion, and & The instructional material provides the students with opportunities: (a) to compare & \\
\hline Quantity & $\begin{array}{l}\text { objects, processes, or properties across size, time, or energy scales, or to dimensions of } \\
\text { familiar objects, timescales, or energies or to identify non-negligible/relevant interactions } \\
\text { at various scales or (b) to predict the response of one variable to changes in another or } \\
\text { identify the relationship between two or more variables from data. }\end{array}$ & \\
\hline Systems and System Models & $\begin{array}{l}\text { The instructional material provides the students with opportunities to identify a system } \\
\text { (by defining its components or boundaries), any assumptions made, and the surroundings } \\
\text { (if necessary), and how the system and surroundings interact with each other. }\end{array}$ & \\
\hline Energy and Matter: Flows, & The instructional material provides the students with opportunities to describe the & \\
\hline Cycles, & $\begin{array}{l}\text { transfer or transformation of energy or matter within or across systems, or between a } \\
\text { system and its surroundings, with explicit recognition that energy and/or matter are } \\
\text { conserved. }\end{array}$ & \\
\hline Structure and Function & $\begin{array}{l}\text { The instructional material provides the students with opportunities to predict or explain a } \\
\text { function or property based on a structure, or to describe what structure could lead to a } \\
\text { given function or property. }\end{array}$ & \\
\hline Stability and Change & $\begin{array}{l}\text { The instructional material provides the students with opportunities to determine if a } \\
\text { system is stable and provide the evidence for this, or what forces, rates, or processes make } \\
\text { a system stable (static, dynamic, or steady state), or under what conditions a system } \\
\text { remains stable, or under what conditions a system is destabilized, and the resulting state. }\end{array}$ & \\
\hline
\end{tabular}

\section{Analysis Framework}

The development of the analysis framework was based on the relevant research literature on threedimensional learning. Within the analysis framework developed, the Three-Dimensional Learning Analysis Inventory (3DLAI), the integration of the three dimensions of science learning (SEPs, CCCs and DCIs) in the content of school textbooks about forces and motion can be assessed. The framework was revised and modified during the analysis process, in case the researchers found vague points and in case of disagreements between the two raters while analyzing the content of school textbooks. Tables 1-3 present the framework for analyzing the content of school textbooks on the basis of SEPs, CCCs and DCIs, respectively.

The part of the 3DLAI framework that was developed for analyzing the content of school textbooks in relation to SEPs integrating in it was based on Appendix $\mathrm{F}$ of NGSS and especially on grades 6-8 (NGSS Lead States, 2013). Through this, the integration of SEPs in the instructional material analyzed can be investigated (Table 1). 
Table 3. The part of 3DLAI referring to disciplinary core ideas about forces and interactions

Disciplinary Core Ide
MS-PS2-1: Forces and
Motion
MS-PS2-2: Forces and
Motion

Description

Motion

The instructional material provides the students with opportunities to explore that for any pair of interacting objects, the force exerted by the first object on the second object is equal in magnitude to the force that the second object exerts on the first, but in the opposite direction (Newton's third law). for the following:

(a) The motion of an object is determined by the sum of the forces acting on it; if the total force on the object is not zero, its motion will change. The greater the mass of the object, the greater the force needed to achieve the same change in motion. For any given object, a larger force causes a larger change in motion.

(b) All positions of objects and the directions of forces and motions must be described in an arbitrarily chosen reference frame and arbitrarily chosen units of size. In order to share information with other people, these choices must also be shared.

MS-PS2-3: Types of The instructional material provides the students with opportunities to know or use Interactions elements for the following: Electric and magnetic (electromagnetic) forces can be attractive or repulsive, and their sizes depend on the magnitudes of the charges, currents, or magnetic strengths involved and on the distances between the interacting objects.

MS-PS2-4: Types of The instructional material provides the students with opportunities to know or use elements for the following: Gravitational forces are always attractive. There is a gravitational force between any two masses, but it is very small except when one or both of the objects have large mass.

MS-PS2-5: Types of The instructional material provides the students with opportunities to know or use elements for the following: Forces that act at a distance (electric, magnetic, and gravitational) can be explained by fields that extend through space and can be mapped by their effect on a test object (a charged object, or a ball, respectively).

The part of the 3DLAI framework that was developed for analyzing the content of school textbooks with regard to the engagement of CCCs in it was based on the 3DLAP framework (Laverty et al., 2016) and Appendix G of NGSS, and especially grades 6-8 (NGSS Lead States, 2013). Through this, the engagement of CCCs in the instructional material analyzed can be investigated (Table 2). It has been noted that these concepts need to be made explicit for students in the instructional material or during the teaching process (NRC, 2012).

The part of the 3DLAI framework that was developed for analyzing the content of school textbooks with regard to the engagement of core ideas about forces and motion was based on the standards proposed by NGSS for the discipline of Physics and the conceptual area of forces and interactions, and for the specific grade (grades 6-8). The engagement of DCIs about forces and interactions in the instructional material analyzed is investigated through this framework (Table 3).

\section{Data Analysis}

The units of analysis were analyzed with regard to the integration of each of the eight SEPs, each of the seven CCCs, and each of the five DCIs on the basis of the 3DLAI analysis framework developed.

To surveying the validity, the 3DLAI framework was granted to two science education experts and reviewed after their comments and the final framework was formulated. Before the beginning of the content analysis of the 61 units of analysis, a pilot analysis was carried out in order for the eight SEPs, the seven CCCs and the five
DCIs to be determined on a small sample of units of analysis of school textbooks. The pilot research was necessary so that the validity of the framework of analysis could be ensured and corrections could be made to the 3DLAI framework that was created.

In order to ensure the reliability of content analysis, the latter was carried out by two independently working science education researchers. They codified every unit of analysis by describing it as "yes" or "no" depending on whether it integrates in this any SEP, CCC and DCIs, and then calculated the degree of agreement of their results by using Cohen's kappa coefficient (Cohen, 1990). Kappa (k) coefficient, in all units of analysis, with regard to the eight SEPs, the seven CCCs and the five DCIs was higher than 0.74. Any disagreements between the researchers were resolved through discussion.

Below are two examples (of units of analysis) followed by their analyses.

\section{Example 1}

Circle the letter or the letters that correspond to the correct answers: (a) action and reaction are equal and act in opposite directions, (b) action and reaction are exerted on the same body, (c) every action is always related to a reaction, (d) the speeds of two bodies on which action and reaction are respectively exerted are varied in the same way.

Analysis of Example 1

The above activity does not provide the students with the opportunities to ask questions, develop and use models, design investigations, analyze data, use mathematical concepts, construct explanations, engage 
Table 4. Frequencies and percentages of science and engineering practices in the content of Greek middle-school Physics textbooks about forces and motion

\begin{tabular}{lcc}
\hline Science and engineering practices & $\mathrm{f}$ \\
\hline Asking questions (for science) and defining problems (for engineering) & 0 & 0 \\
Developing and using models & 20 & 32.8 \\
Planning and carrying out investigations & 2 & 3.3 \\
Analyzing and interpreting data & 2 & 3.3 \\
Using mathematics and computational thinking & 10 & 16.4 \\
Constructing explanations (for science) and designing solutions (for engineering) & 17 & 27.9 \\
Engaging in argument from evidence & 3.9 \\
Obtaining, evaluating, and communicating information & 2 & 3.3 \\
\hline
\end{tabular}

Table 5. Frequencies and percentages of crosscutting concepts in the content of Greek middle-school Physics textbooks about forces and motion

\begin{tabular}{|c|c|c|}
\hline Crosscutting Concepts & $\mathrm{f}$ & $\%$ \\
\hline Patterns & 0 & 0 \\
\hline Cause and Effect: Mechanism and Explanation & 22 & 36 \\
\hline Scale, Proportion, and Quantity & 16 & 26.2 \\
\hline Systems and System Models & 12 & 19.7 \\
\hline Energy and Matter: Flows, Cycles, and Conservation & 0 & 0 \\
\hline Structure and Function & 0 & 0 \\
\hline Stability and Change & 10 & 16.4 \\
\hline
\end{tabular}

in argument or study a text in order to extract information. As a result, through this activity, the students do not engage in any of the eight SEPs. It is therefore concluded that the specific unit of analysis, in accordance with the 3DLAI framework, is described as "no" in the integration of practices. Furthermore, none of the seven CCCs integrates in this activity. Finally, as for the existence of DCIs, the core idea MS-PS2-1, which is related to Newton's third law, integrates in this activity. As a result, the specific activity integrates one learning dimension.

\section{Example 2}

A rubber lies stable on your desk. Draw the forces acting on the rubber and state by which object each of them comes from. Classify them into contact and non contact forces. Repeat the same steps while moving the rubber in one direction along the page of your notebook in order to erase a sentence.

\section{Analysis of Example 2}

The above activity integrates the practice that is related to the development and use of models (by drawing forces represented as vectors). However, no other practices integrate in this activity. Two CCCs (cause and effect as well as stability and change) integrate in this activity. Also, the core idea MS-PS2-2, which is related to Newton's second law, integrates in this activity. Hence, the specific activity integrates three dimensions of learning.

After analyzing the 61 units of analysis, the frequencies and percentages of SEPs, CCCs and DCIs integrating in the content analyzed were identified. It is noted that more than one SEP, CCC or DCI might integrate in one unit of analysis.

\section{RESULTS}

Data analysis enabled investigation into the integration of SEPs, CCCs and DCIs in the content about forces and motion of Greek middle-school textbooks.

Table 4 shows the frequencies and percentages of SEPs integrating in the 61 units of analysis. From the Table 4 emerged that practices related to developing and using models, constructing explanations, and using mathematics and computational thinking integrate more in the units of analysis, while the integration of the other practices is limited.

Table 5 shows the frequencies and percentages of CCCs integrating in the 61 units of analysis. Table 5 shows that the CCCs referring to cause and effect integrates more in the units of analysis, followed by CCCs referring to scale, proportion and quantity, systems, and system models as well as stability and change. The integration of the other CCCs is particularly limited.

Table 6 shows the frequencies and percentages of DCIs about forces and interactions integrating in the 61 units of analysis about the conceptual area of forces and motion. It follows from Table 6 that DCIs MS-PS2-1 (Newton's third law) and MS-PS2-2 (Newton's second law) integrate more in the units of analysis. However, they only integrate in almost half of the units of analysis.

Table 7 shows the frequencies and percentages of the number of dimensions of science learning integrating in the 61 units of analysis about the conceptual area of forces and motion. It is concluded by the Table 7 that not all three dimensions (SEPs, CCCs and DCIs) appear in the majority of the units of analysis (70.5\%). All three dimensions integrate in only one third of the units of analysis. 
Table 6. Frequencies and percentages of disciplinary core ideas in the content of Greek middle-school Physics textbooks about forces and motion

\begin{tabular}{lcc}
\hline Disciplinary Core Ideas & $\mathrm{f}$ \\
\hline MS-PS2-1 & 14 & 22.9 \\
MS-PS2-2 & 15 & 24.6 \\
MS-PS2-3 & 0 & 0 \\
MS-PS2-4 & 3 & 4.9 \\
MS-PS2-5 & 0 & 0 \\
\hline
\end{tabular}

Table 7. Frequencies and percentages of occurrence of dimensions of science learning in the content of Greek middle-school Physics textbooks about forces and motion

\begin{tabular}{lcc}
\hline Number of Dimensions of Science Learning & f & 23.0 \\
No dimensions & 14 & 29 \\
One or two dimensions & 29.5 & 18 \\
Three dimensions & 29.5 \\
\hline
\end{tabular}

\section{DISCUSSION AND CONCLUSIONS}

According to the US National Research Council (NRC), "learning is defined as the combination of both knowledge and practice" (NRC, 2012, p. 254). More specifically, it is considered necessary that science education be based on three dimensions of science learning (DCIs, SEPs, and CCCs). However, research studying the integration of these dimensions in the instructional material used in teaching, and especially in school textbooks, is particularly limited. The present study at first intended to propose an analysis framework (regarding the three dimensions of science learning) and then, through this framework, to study the integration of these three dimensions in the content of Greek middleschool Physics textbooks about forces and motion.

A framework of analysis was proposed for studying the integration of SEPs, CCC s and DCIs in the content of school textbooks. The proposed 3DLAI framework of analysis investigates the integration of each practice, each CCC and each core idea in the reports and activities of the textbooks. It should be noted that the section of the framework referring to DCIs is restricted to the domain of forces and motion. For analyzing more domains, this section should be configured based on the DCIs reported in NGSS (NGSS Lead States, 2013). Despite the above restriction, this framework can be used in both the field of teaching practice and the field of research. In the field of teaching practice, the 3DLAI framework can be used by the teachers for analyzing both the instructional material they are provided with and the additional instructional material (printed or digital) they possibly seek and find in other sources in order to complete or enrich the material they are provided with. Helped by 3DLAI, the teacher can find out whether the goals they have set regarding SEPs, CCCs and DCIs integrate in the instructional material they are to use. Moreover, with the use of this framework, teachers can modify the activities of the instructional material in order to address any weaknesses they possibly have. In the field of research, the 3DLAI framework can be used by researchers for analyzing the instructional material used in science teaching, but also for producing and analyzing new instructional material that will be produced in order to find out whether the new instructional material has been developed based on the three-dimensional learning approach. However, it should be noted that 3DLAI has been applied for analyzing only one chapter of Greek school textbooks and, as a result, this is a restriction. Further research is required in which this framework will be used for analyzing more textbooks so that its clarity and efficacy can be improved for both researchers and teachers.

Only a limited number of SEPs, and only to a limited extent, integrate in the instructional material that was analyzed. In particular, it was found that the practice of asking questions and defining problems was completely absent, while the practices of planning and carrying out investigations, analyzing and interpreting data, obtaining, evaluating, and communicating information and engaging in argument from evidence integrated to a very minor extent. Consequently, no opportunities to use practices are provided to a sufficient extent to the students through the instructional material (Greek middle-school Physics textbooks about forces and motion). However, the integration of students in SEPs is important since it can help them understand the process for developing scientific knowledge, construct science ideas and concepts, attract their curiosity and interest, and encourage further research (Duschl et al., 2007). Indeed, research data demonstrates that instruction based on these practices is significantly beneficial for students' learning (Grooms et al., 2018; McNeill \& Krajcik, 2007; Windschitl et al., 2008).

In addition, in the units of analysis that were analyzed, the integration of CCCs is limited. In particular, it was found that the CCCs related to cause and effect engages to a greater extent, followed by the concept related to scale, proportion and quantity. The above finding relating to the limited integration of CCCs in school textbooks is in line with the results of other research studies (Fick, 2018). However, when CCCs engage in teaching, they can help students understand the content (e.g., a specific science idea) and support 
them to understand the cross-discipline nature of the crosscutting themes (Rivet et al., 2016).

As for DCIs, it was found that mainly two of them (ideas related to Newton's second and third laws) integrate in only half of the units of analysis. The integration of the idea related to gravitational forces is particularly limited, while the other DCIs are absent from the instructional material that was analyzed. The absence of these core ideas can be attributed to the fact that the research conducted concerned textbooks of only one grade of middle school, while they are included in school textbooks of other grades of secondary education. However, the results obtained from the textbooks that were analyzed demonstrate that their content does not put emphasis on DCIs about forces and interactions, as they have been specified by NGSS. Focusing on a limited number of DCIs is necessary rather than superficially studying all science ideas (NGSS Lead States, 2013). Focusing on a few core ideas allows students to develop a deep understanding of important ideas in science coherently across school grades and helps them explain a wide range of phenomena (NRC, 2012, 2013).

In addition, the content analysis of the textbooks analyzed showed that most activities either integrate one or two dimensions of science learning or they do not integrate any of them. Only some units of analysis (almost 1 of 3 ) integrate all three dimensions. This finding is in agreement with research findings demonstrating that the teachers tend to develop or use activities integrating only one dimension of science learning (Anderson et al., 2018). However, it has been emphasized that the learning process should not be focused on one isolated dimension, but on explaining the phenomena through all three dimensions. "If we want students to learn content and apply their knowledge, then they must use the SEPs and CCCs with the DCIs together. None of the dimensions can be used in isolation; they work together so that students can build deeper understanding" (Krajcik, 2015, p. 50). Therefore, no opportunities are provided to the students through the content of school textbooks that were analyzed in the present study to engage with reports or activities integrating all three dimensions of science learning so that they can deeply understand what they are taught.

The present study investigated the integration of the three dimensions of science learning in the content of Greek middle-school Physics textbooks about forces and motion but did not investigate the implementation of these textbooks by the teachers. However, research data demonstrates that when the teachers use a textbook, they tend to use it as it is or with minor changes (Kang et al., 2016). As a result, studying school textbooks is particularly important and the present research paper contributes to this direction. Studying instructional material used in teaching and the way it is used is important because it can contribute to both designing future instructional material and training teachers (Kaldaras et al., 2020).

The present study focused on investigating the SEPs, CCCs and DCIs integrating in only one chapter of middle-school Physics textbooks. However, the analysis of all the chapters of school science textbooks of both primary and secondary education that are used by the Greek educational system would provide us with a more comprehensive picture of the SEPs, CCCs and DCIs in which the students engage. Moreover, it would be of great research interest to analyze other countries' school science textbooks about forces and motion with regard to the integration of the three dimensions of science learning in them and compare the results. It should be stressed that the present study focused only on analyzing the content of school textbooks rather than on their implementation within the school framework by the teachers. It is therefore proposed that the teaching process be analyzed so that it can be investigated whether the teachers provide the students with opportunities to engage in activities integrating all three dimensions of science learning. Finally, further research is required for developing instructional material with activities integrating three dimensions of science learning and for studying the impact of its implementation on students' learning outcomes.

Author contributions: All authors have sufficiently contributed to the study, and agreed with the results and conclusions.

Funding: No funding source is reported for this study.

Declaration of interest: No conflict of interest is declared by authors.

\section{REFERENCES}

Abd-El-Khalick, F., Waters, M., \& An-Phong, L. (2008). Representations of nature of science in high school chemistry textbooks over the past four decades. Journal of Research in Science Teaching, 45(7), 835-855. https:// doi.org/10.1002/tea.20226

Achieve. (2016, September). EQuIP rubric for lessons and units: Science. NGSS. https://www.nextgenscience. org/sites/default/files/EQuIPRubricforSciencev3 .pdf

Aldahmash, A. H., Mansour, N. S., Alshamrani, S. M., \& Almohi, S. (2016). An analysis of activities in Saudi Arabian middle school science textbooks and workbooks for the inclusion of essential features of inquiry. Research in Science Education, 46(6), 879-900. https:/ / doi.org/10.1007/s11165-015-9485-7

Anderson, C. W., de los Santos, E. X., Bodbyl, S., Covitt, B. A., Edwards, K. D., Hancock, J. B., Lin, Q., Thomas, C. M., Penuel, W., \& Welch, M. M. (2018). Designing educational systems to support enactment of the next generation science standards. Journal of Research in Science Teaching, 55, 1026-1052. https://doi.org/10.1002/tea.21484 
Bell, R. L., Smetana, L., \& Binns, I. (2005). Simplifying inquiry instruction: Assessing the inquiry level of classroom activities. The Science Teacher, 72(7), 3033.

Braswell, J. S., Lutkus, A. D., Grigg, W. S., Santapau, S. L., Tay-Lim, B., \& Johnson, M. (2001). The nation's report card: Mathematics 2000. National Center for Education Statistics. http://nces.ed.gov/pub search/pubsinfo.asp?pubid $=2001517$

Bulunuz, M., Jarrett, O. S., \& Martin-Hansen, L. (2012). Level of inquiry as motivator in an inquiry methods course for Preservice elementary teachers. School Science and Mathematics, 112(6), 330-339. https:// doi.org/10.1007/s11165-015-9485-7

Bybee, R. (2014). Guest editorial: The BSCS 5E instructional model: Personal reflections and contemporary implications. Science and Children, 51(8), 10-13. https://doi.org/10.2505/4/sc14_051_ 08_10

Carson, R., \& Rowlands, S. (2005). Mechanics as the logical point of entry for the enculturation into scientific thinking. Science \& Education, 14, 473-493. https:// doi.org/10.1007/s11191-004-1791-9

Cellitti, J., Likely, R., Moy, M. K., \& Wright, C. G. (2018, June). A Content Analysis of NGSS Science and Engineering Practices in K-5 Curricula. Paper presented at 2018 ASEE Annual Conference and Exposition, Salt Lake City, Utah. https:/ / peer.asee.org/29667

Chiappetta, L. E., \& Fillman, A. D. (2007). Analysis of five high school biology textbooks used in the united states for inclusion of the nature of science. International Journal of Science Education, 29(15), 1874-1868.

https:/ / doi.org/10.1080/09500690601159407

Cohen, J. (1990). Things I have learned (so far). American Psychologist, 45(12), 1304-1312. https://doi.org/ 10.1037/0003-066x.45.12.1304

Davis, J. (2009). Understanding the influence of two Mathematics textbooks on prospective secondary teachers' knowledge. Journal of Mathematics Teacher Education, 12(5), 365-389. https:/ / doi.org/10.1007/ s10857-009-9115-2

Devetak, I., \& Vogrinc, J. (2013). The criteria for evaluating the quality of the science textbooks. In M. S. Khine (Ed.), Critical analysis of science textbooks: Evaluating instructional effectiveness (pp. 3-15). Springer. $\quad$ https://doi.org/10.1007/978-94-0074168-3_1

Driver, R. (1989). Students' conceptions and the learning of science. International Journal of Science Education, 11(5), 481-490. https:/ / doi.org/10.1080/095006989 0110501

Dunne, J., Mahdi, A. E., \& O'Reilly, J. (2013). Investigating the potential of Irish primary school textbooks in supporting inquiry-based science education (IBSE). International Journal of Science Education, 35(9), 1513-1532. https://doi.org/ 10.1080/09500693.2013.779047

Duschl, R. (2012). The second dimension-crosscutting concepts: Understanding a framework for $\mathrm{K}-12$ science education. The Science Teacher, 79, 34-38.

Duschl, R., Schweingruber, H. \& Shouse, A. (2007). Taking science to school: Learning and teaching science in grades K-8. The national Academies Press.

Fan, L., \& Zhu Y. (2007). Representation of problemsolving procedures: A comparative look at China, Singapore, and US mathematics textbooks. Educational Studies in Mathematics, 66(1), 61-75. https:// doi.org/10.1007/s10649-006-9069-6

Fauskanger, J., \& Mosvold, R. (2014). Innholdsanalysens muligheter i utdanningsforskning [The possibilities of content analysis in educational research]. Norsk Pedagogisk Tidsskrift, 98(02|2), 127-139. https:// doi.org/10.18261/ISSN1504-2987-2014-02-07

Fay, M. E., Grove, N. P., Towns, M. H., \& Bretz, S. L. (2007). A rubric to characterize inquiry in the undergraduate chemistry laboratory. Chemistry Education Research and Practice, 8(2), 212-219. https:/ / doi.org/10.1039/B6RP90031C

Fick, S. J. (2018). What does three dimensional teaching and learning look like?: Examining the potential for crosscutting concepts to support the development of science knowledge. Science Education, 102(1), 535. https:// doi.org/10.1002/sce.21313

Germann, P. J., Haskins, S., \& Auls, S. (1996). Analysis of nine high school biology laboratory manuals: Promoting scientific inquiry. Journal of Research in Science Teaching, 33(5), 475-499. https://doi.org/ 10.1002/(sici)1098-2736(199605)33:53.0.co;2-o

Grooms, J., Sampson, V., \& Enderle, P. (2018). How concept familiarity and experience with scientific argumentation are related to the way groups participate in an episode of argumentation. Journal of Research in Science Teaching, 55(9), 1264-1286. https:// doi.org/10.1002/tea.21451

Halim, L., Yong, T., \& Meerah, T. (2014). Overcoming students' misconceptions on forces in equilibrium: An action research study. Creative Education, 5(11), 1032-1042. https:/ / doi.org/10.4236/ce.2014.511117

Hatzinikita V., Dimopoulos, K., \& Christidou, V. (2008). PISA test items and school textbooks related to science. Science Education, 92(4), 664-687. https:// doi.org/10.1002/sce.20256

Herron, M. D. (1971). The nature of scientific enquiry. The School Review, 79(2), 171-212. https:/ / doi.org/ $10.1086 / 442968$ 
Inkinen, J., Klager, C., Juuti, K., Schneider, B., SalmelaAro, K., Krajcik, J., \& Lavonen, J. (2020). High school students' situational engagement associated with scientific practices in designed science learning situations. Science Education, 104(4), $667-$ 692. https://doi.org/10.1002/sce.21570

Jimoyiannis, A., Komis, V. (2003). Investigating Greek students' ideas about forces and motion. Research in Science Education 33, 375-392. https://doi.org/ 10.1023/A:1025457116654

Kahveci, A. (2009). Quantitative analysis of science and chemistry textbooks for indicators of reform: A complementary perspective. International Journal of Science Education, 32(11), 1495-1519. https:/ / doi.org /10.1080/09500690903127649

Kaldaras, L., Akaeze, H., \& Krajcik, J. (2020). Developing and validating next generation science standardsaligned learning progression to track threedimensional learning of electrical interactions in high school physical science. Journal of Research in Science Teaching, 58(4), 589-618. https://doi.org/ 10.1002/tea.21672

Kang, H., Windschitl, M., Stroupe, D., \& Thompson, J. (2016). Designing, launching, and implementing high quality learning opportunities for students that advance scientific thinking. Journal of Research in Science Teaching, 53(9), 1316-1340. https://doi. org/10.1002/tea.21329

Kollas S., Stavrou D., \& Halkia Kr. (2007, February). A quantitative analysis of Greek Physics textbooks with respect to scientific literacy. Proceedings of IOSTE International Meeting: Critical Analysis of School Science Textbooks. Hammamet, Tunisia.

Krajcik, J. (2015). Three-dimensional instruction: Using a new type of teaching in the science classroom. The Science Teacher, 82(8), 50-52. https://doi.org/ 10.2505/4/tst15_082_08_50

Krajcik, J., Codere, S., Dahsah, C., Bayer, R., \& Mun, K. (2014). Planning instruction to meet the intent of the Next Generation Science Standards. Journal of Science Teacher Education, 25(2), 157-175. https:/ / doi.org/10.1007/s10972-014-9383-2

Krippendorff, K. (2013). Content analysis. An introduction to its methodology (3rd ed.). Sage Publications.

Laverty, J. T., Underwood, S. M., Matz, R. L., Posey, L. A., Carmel, J. H., Caballero, M. D., Fata-Hartley, C. L., Ebert-May, D., Jardeleza, S. E., \& Cooper, M. M. (2016). undefined. PLOS ONE, 11(9), e0162333. https:/ / doi.org/10.1371/journal.pone.0162333

Lederman, J. S. (2009). Teaching scientific inquiry: Exploration, directed, guided, and opened-ended levels. In National geographic science: Best practices and research base (pp. 8-20). Hapton-Brown Publisher.
Lee, O., Miller, E. C., \& Januszyk, R. (2014). Next generation science standards: All standards, all students. Journal of Science Teacher Education, 25(2), 223-233. https://doi.org/10.1007/s10972-0149379-y

Liu, Y., \& Khine, M. S. (2016). Content analysis of the diagrammatic representations of primary science textbooks. Eurasia Journal of Mathematics, Science and Technology Education, 12(8), 1937-1951. https:/ / doi.org/10.12973/eurasia.2016.1288a

Ma, Y., Wang, T., Wang, J., Chen, A. L. R., \& Yan, X. (2019). A comparative study on scientific inquiry activities of Chinese science textbooks in high schools. Research in Science Education. https:/ / doi.org/10.1007/s11165-019-09902-Z

McNeill, K. L., \& Krajcik, J. (2007). Scientific explanations: Characterizing and evaluating the effects of teachers' instructional practices on student learning. Journal of Research in Science Teaching, 45(1), 53-78. https://doi.org/10.1002/ tea.20201

Miller, E., Manz, E., Russ, R., Stroupe, D., \& Berland, L. (2018). Addressing the epistemic elephant in the room: Epistemic agency and the next generation science standards. Journal of Research in Science Teaching, 55(7), 1053-1075. https:/ / doi.org/10.1002 /tea.21459

Moulton, J. (1997). How do teachers use textbooks? A review of the research literature. U.S. Agency for International Development, Health and Human Resources Analysis for Africa Project.

National Research Council (NRC). (1996). National Science Education Standards. The National Academies Press. https:/ / doi.org/10.17226/4962

National Research Council (NRC). (2012). A framework for K-12 science education: Practices, crosscutting concepts, and core ideas. The National Academies Press.

National Research Council (NRC). (2013). Education for life and work: Developing transferable knowledge and skills in the 21st century. National Academies Press

National Research Council (NRC). (2014). Developing assessments for the next generation science standards. National Academies Press.

Newton, D. P., \& Newton L. D. (2006). Could elementary mathematics textbooks help give attention to reasons in the classroom? Educational Studies in Mathematics, 64(1), 69-84. https:/ / doi.org/10.1007/ s10649-005-9015-Z

NGSS Lead States. (2013). Next generation science standards: For states, by states. The National Academies Press.

Organisation for Economic Co-operation and Development (OECD). (2007). PISA 2006: Science competencies for tomorrow's World (Volume 1): Analysis. OECD. 
Organisation for Economic Co-operation and Development (OECD). (2013). PISA 2012 assessment and analytical framework: Mathematics, reading, science, problem solving and financial literacy. OECD.

Osborne, J. (2014). Teaching scientific practices: Meeting the challenge of change. Journal of Science Teacher Education, 25(2), 177-196. https:/ / doi.org/10.1007/ s10972-014-9384-1

Pruitt, S.L. (2014). The next generation science standards: The features and challenges. Journal of Science Teacher Education, 25(2), 145-156. https://doi.org/ 10.1007/s10972-014-9385-0

Reys, R., Reys, B., Lapan, R., Holliday, G., \& Wasman, D. (2003). Assessing the impact of Standards-based middle grades mathematics curriculum materials on student achievement. Journal for Research in Mathematics Education, 34(1), 74-95. https:/ / doi.org /10.2307/30034700

Rivet, A. E., Weiser, G., Lyu, X., Li, Y., \& Rojas-Perilla, D. (2016). What are crosscutting concepts in science? Four metaphorical perspectives. Journal of Science Teacher Education, 25(2), 157-175.

Schwab, J. J. (1962). The teaching of science as enquiry. In J. J. Schwab \& P. F. Brandwein (Eds.), The teaching of science (pp. 1-103). Harvard University Press.

Schwarz, C., Passmore, C., \& Reiser, B. J. (Eds.). (2017). Helping students make sense of the world using Next Generation Science and Engineering Practices. NSTA Press.

Shwartz, Y., Weizman, A., Fortus, D., Krajcik, J., \& Reiser, B. (2008). The IQWST experience: Using coherence as a design principle for a middle school science curriculum. The Elementary School Journal, 109(2), 199-219. https:/ / doi.org/10.1086/590526

Sothayapetch, P., Lavonen, J., \& Juuti, K. (2013). An analysis of science textbooks for grade 6: The electric circuit lesson. Eurasia Journal of Mathematics Science and Technology Education, 9(1), 59-72. https:/ / doi.org/10.12973/eurasia.2013.916a
Strijbos, J., Martens, R. L., Prins, F. J., \& Jochems, W. M. (2006). Content analysis: What are they talking about? Computers $\mathcal{E}$ Education, 46(1), 29-48. https://doi.org/10.1016/j.compedu.2005.04.002

Swanepoel, S. (2010). The assessment of the quality of science education textbooks: conceptual framework and instruments for analysis (Doctoral dissertation). http:/ / uir.unisa.ac.za/bitstream/handle/10500/4 041/thesis_swanepoel_s.pdf?sequence $=1$

Tekkumru-Kisa, M., Stein, M. K., \& Schunn, C. (2015). A framework for analyzing cognitive demand and content-practices integration: Task analysis guide in science. Journal of Research in Science Teaching, 52(5), 659-685. https:/ / doi.org/10.1002/tea.21208

Vojír̆, K., \& Rusek, M. (2019). Science education textbook research trends: A systematic literature review. International Journal of Science Education, 41(11), 1496-1516. https:/ / doi.org/10.1080/09500693.2019.1613584

Weiss, I. R., Nelson, B. H., Boyd, S. E., \& Hudson, S. B. (1989). Science and Mathematics Education Briefing Book. Horizon Research, Inc, Chapel Hill, NC.

Wenning, C. J. (2007). Assessing inquiry skills as a component of scientific literacy. Journal of Physics Teacher Education Online, 4(2), 21-24.

Windschitl, M., Thompson, J., \& Braaten, M. (2008). How novice science teachers appropriate epistemic discourses around model-based inquiry for use in classrooms. Cognition and Instruction, 26(3), 310-378. https:/ / doi.org/10.1080/07370000802177193

Yang, W., \& Liu., E. (2016). Development and validation of an instrument for evaluating inquiry-based tasks in science textbooks. International Journal of Science Education, 38(18), 2688-2711. https://doi.org/ $10.1080 / 09500693.2016 .1258499$

Yang, W., Liu, C., \& Liu., E. (2019). Content analysis of inquiry-based tasks in high school biology textbooks in Mainland China. International Journal of Science Education, 41(6), 827-845. https:/ / doi.org/10.1080/09500693.2019.1584418

\section{http://www.ejmste.com}

